Page 3I - 50

\title{
ISLAMIC BANKING EFFICIENCY: COMPARATIVE STUDIES BETWEEN MALAYSIA AND INDONESIA
}

\author{
Ika Yulita, Sofyan Rizal \\ Lingkar Studi Ekonomi Syariah, UIN Syarif Hidayatullah Jakarta \\ ikayulita19@gmail.com, sofyan.rizal@uinjkt.ac.id
}

\begin{abstract}
.
The purpose of this research is to measure efficiency level of sharia banking in Malaysia and Indonesia countries and to analyse the factors affecting the level of efficiency of sharia banking for both countries. This research uses DEA (Data Envelopment Analysis) method in order to test the assumptions of Variable Return to Scale (VRS), and uses Kolmogorov-Smirnov and Mann Whitney UTest in order to test normality, and uses regression dummy variable of the data from the first quarter of $201 \mathrm{I}$ until the fourth quarter of 2014. The research shows overall level of efficiency of sharia banking in Malaysia and Indonesia countries are fluctuating. Based on result, sharia banking in Indonesia more efficient than sharia banking in Malaysia; however, there is no significant differences among them. The reasons of this inefficiency are deposits, total financing, fixed asset, and personnel cost. However, operational income is the most efficient variable for both countries.
\end{abstract}

Keywords: Efficiency; Islamic Banking; Data Envelopment Analysis

\begin{abstract}
Abstrak.
Tujuan penelitian ini adalah untuk mengukur tingkat efisiensi Bank syariah antara Malaysia dan Indonesia serta menganalisis faktor-faktor yang mepengaruh tingkat efisiensi Bank Syariah untuk kedua negara tersebut. Penelitian ini menggunakan metode DEA (Data Envelopment Analysis) untuk megukur efisensi asumsi Variabel Return to Scale (VRS), dan menggunakan kolmogorov smirnov dan Mann Whitney U-Test untuk menguji normalitas data, serta uji regresi variabel dummy dari periode kuartal I Tahun 20II sampai kuartal IV tahun 20I4. Penelitian ini menunjukkan bahwa secara keseluruhan tingkat efisiensi perbankan syariah di Malaysia dan Indonesia bersifat fluktuatif. Berdasarkan hasil penelitian, perbankan syariah di Indonesia lebih efisien dibadingkan perbankan syariah di Malaysia; namun tidak ada perbedaan yang signifikan diantara keduanya. Penyebab inefisiensi tersebut adalah DPK, total pembiayaan, aset tetap, dan biaya personalia. Namun pendapatan operasional merupakan variabel yang paling efisien bagi kedua negara tersebut.

Kata Kunci: Efisiensi; Perbankan Syariah; Data Envelopment Analysis
\end{abstract}

Received: January 5, 2016; Revised: February 15, 2016; Approved: March 20, 2016 
Islamic Banking Efficiency: Comparative Studies

Ika Yulita, Sofyan Rizal

\section{INTRODUCTION}

The prospect of Islamic finance industry growth in Asia is very strong from time to time. It brings business opportunities for various industries, especially in terms of sharia banking and capital markets sector. In 2013, The Islamic finance industry in Asia consisted of sharia banks (total assets of USD 189 or $49 \%$ of the total assets of Islamic finance), sukuk (total assets of USD I77 or 45\%), Islamic funds asset under management (total assets of USD 18 or 5\%), and takaful (total assets of USD 3 or 1\%). The largest centre of Islamic Finance in Asia is Malaysia, Indonesia, Pakistan, and Bangladesh. Islamic finance also began to grow in several Asian countries including Singapore, Brunei Darussalam, the Philippines, Hong Kong, Kazakhstan, Azerbaijan and Thailand.

From the data, it can be seen that Malaysia has the highest approximately $70 \%$ of Islamic banking total assets in Asia. This indicates that the liberalization of financial sector performed continuously and sustained by the government's role in developing the Islamic banking sector which makes Malaysia as the drive advancement shaft of trade and expanding global Islamic finance industry. Malaysia Islamic finance market share reached about $20 \%$. Asset growth is increase significantly and will continue to elevate with rising global market share of Islamic banking.

According to the World Islamic Banking Competitiveness Report 2014 by Ernst \& Young, with a population of approximately 1.6 billion Moslems, or nearly a quarter of the world's population makes Islamic finance market is very broad. Globally, the average growth of Islamic banking assets reached 17\% in recent years. While the Global Islamic Economy report 2013, Thomson Reuters suggests that the assets of Islamic financial market is currently around USD 985 billion, less than one percent of global banking assets. In fact, the market potential can grow up to USD 4,095 billion.

In Asia, the Moslem population is of over 60 per cent Moslem in the world which is the heart of the Islamic finance development. Indonesia has the largest Moslem population and Malaysia is an Islamic finance market leading in the world with assets of USD 412 billion in 2012. Islamic finance market potential is enormous, representing 10 of the 25 markets that are growing faster in the world andhas the 
largest Moslem population (EY, Analyst Report 2014). Indonesia has a Moslem population of about $\mathbf{2 5 0}$ million people. It is likely to be the next Islamic financial major market. The Islamic banking sector is expected to grow five-fold from $20 \mathrm{II}$ to 2015 . In Malaysia, Islamic financial assets are expected to reach $40 \%$ of the banking sector in 2020 (Asia Briefing, 2014).

Along with the integration of ASEAN Economic Community (AEC) 2015 endorsed by the heads of the ASEAN member states in October 2003 through the Declaration of ASEAN Concord II (Bali Concord II) and the agreement in Cebu in 2007, natural framework of the ASEAN establishment as a production base and a single market, the liberalization of the services sector, including financial services sector becomes a strategic move. Lodging in the financial and monetary sector, financial services liberalization in the region becomes one of the most important steps in roadmap financial integration implementation in ASEAN, or better known by the RIA-Fin (Roadmap for Monetary and Financial Integration of ASEAN) (Setiawan, 20II).

Islamic banking as part of the national banking system has an important rolein the economy. The role of Islamic banking is to encourage economic activity of a country then if it is not properly manage, it will trigger the economic crisis. Banking efficiency indicator is a reflection of the banking soundness and become a benchmark of public confidence. As an intermediary function where market share will be wide open. Banks were a lower in collecting third party funds (DPK) and also lower in the distribution of funds, indicates inefficient. The ability to collect public funds (DPK) well and passes well and can minimize the cost to obtain the maximum profit that the bank is efficient. Islamic banking, which grows rapidly, is charged to have a good level of efficiency in the foreign banking competition. Moreover, there will AEC 2015 and QAB 2020.

Research on the efficiency level competition among banks in ASEAN countries is very important to study as a tool to prepare the economy countries that are fused of the AEC (ASEAN economic Community) and QAB (Qualified ASEAN Banks) members, which are expected to support global economies. In order to remain in operation, each financial entity must be measurable results of its work in the form of performance. Efficiency in banking 
Islamic Banking Efficiency: Comparative Studies

Ika Yulita, Sofyan Rizal

system is one of the things that are very important in measuring a bank performance to carry out its operations. The ratio of Operating Expenses to Operating Income (BOPO) and Net Operating Margin (NOM) is often used as a reference in analysing the efficiency of which is one component in the analysis of CAMEL (Capital Asset Management Equity Liability).

Based on Alamsyah (20I2) presented that the ratio of BOPO and NOM Islamic banking in Indonesia is much higher than Malaysia. Hence, Islamic Bank in Indonesia is still less efficient than Malaysia. Here the comparison data of BOPO and NOM Islamic banking in Indonesia and Malaysia:

Table I.

The Comparison of Islamic Banking Indicator among Countries

BOPO

\begin{tabular}{lllll} 
Bank Sample & Indonesia & Malaysia & Indonesia & Malaysia \\
\hline I $^{\text {st }}$ Sample & 76.54 & 29.59 & 2.14 & 2.78 \\
$2^{\text {nd }}$ Sample & 85.52 & 39.50 & 5.01 & 2.93 \\
$3^{\text {rd }}$ Sample & 98.56 & 64.30 & 7.59 & 4.07 \\
Average & $\mathbf{8 6 . 8 7}$ & $\mathbf{4 4 . 4 6}$ & $\mathbf{4 . 9 I}$ & $\mathbf{3 . 2 6}$
\end{tabular}

Source: Alamsyah, 2012

However, BOPO and NOM ratio has a weakness in measuring the efficiency i.e. difficult to generalize whether a ratio is good or bad, difficult to say whether a company is strong or weak and it does not measure cost of capital (Endri, 2008). In addition, the ratio of CAMEL also paid little attention to the efficiency factor. To overcome the existing deficiencies in measuring company performance ratio analysis, Frontier approach was developed to measure the company efficiency. One of Frontier approach often used in analysing bank efficiency is Data Envelopment Analysis (DEA). DEA is a mathematical programming technique for measuring the efficiency of Decision Making Unit (DMU). This method has an advantage over methods parametric. The advantage in using a non parametric method is that we can identify the unit that is used as a reference.

Therefore, the efficiency level of competition-related research among Islamic Bank in Malaysia and Indonesia is very important to be studied in preparing facing the $A E C$ in 2015 and $Q A B$ in 2020, hence the need to evaluate the efficiency performance 
to make improvements and see the object of this study involves the Islamic banking in Malaysia and Indonesia. It is a reflection of the level of competition among two governments as well as other policy solutions can be scientific considerations for regulators.

\section{METHOD}

The object of this variable study includes 19 Islamic Banks (full-fledged Islamic banks) residing in Malaysia and Indonesia during the first quarter of 2011 - the fourth quarter of 2014. In this study, the determination of input and output variables to measure the efficiency of used Data Envelopment Analysis (DEA) intermediation approach that can be used to measure the efficiency performance. Researchers previously have done the research about efficiency in Islamic bank sareSufian (2006), Ascarya and Yumanita (2008a, 2008b); Rusdian (20I3), Warninda and Hosen (20I5), Adawiyah (20I5), Hosen and Rahmawati (2016) . Therefore, it is assumed that Islamic banks generate operational income, and the total financing using fixed assets, the cost of personnel, and third party fund (DPK). The assumption used is the Variable of Return to Scale (VRS) / input-oriented taken in this study because sister bank management is easier to improve performance for input in terms supervision for reducing the company's expenses. It will be easier for management to supervise the input used to increase a higher output.

DEA is a linear programming technique to assess the performance of Decision making units (DMU) or a bank in an industry operates in relation to other banks in the sample. In the DEA approach, linear programming is used to maximize the ratio between input and output (Charnes, Cooper, and Rhodes, 1978) as well as for DMUs Islamic banking industry. For DMUs banking industry that become the object of study of the entire sample input and output respectively denoted (marked) by then ' $n$ ' and ' $m$ ', where $n=$ input $=$ input and $m=$ output. The bank efficiency is calculated by an equation:

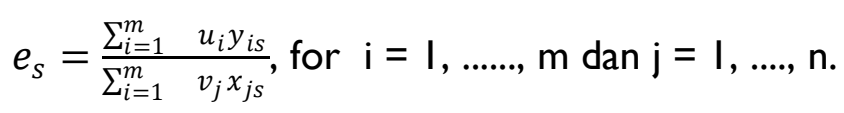


Islamic Banking Efficiency: Comparative Studies

Ika Yulita, Sofyan Rizal

$y_{\text {is }}$ : Output total (i) which is resulted by bank (s)

$\mathrm{x}_{\mathrm{js}} \quad$ : Input total (j) which is used by bank (s)

$\mathrm{u}_{\mathrm{i}} \quad$ : Output weight

$v_{j} \quad$ : Input weight

The above equation points to the use of the input variables and one output variable. Efficiency ratio $\left(e_{s}\right)$, then maximized with the following constraints:

$$
e_{s}=\frac{\sum_{i=1}^{m} \quad u_{i} y_{i s}}{\sum_{i=1}^{m} \quad v_{j} x_{j s}} \leq \mathrm{I}, \mathrm{r}=\mathrm{I}, \ldots ., \mathrm{n} . \text { where } \mathrm{u}_{\mathrm{i}} \text { and } \mathrm{v}_{\mathrm{j}} \geq 0
$$

Charnes, Cooper, and Rhodes (1978) suggested that part of this linear programming can be changed to be ordinary linear programming by the following:

$$
\begin{aligned}
& e_{s}=\sum_{i=1}^{m} u_{i} y_{i s} \text { Maximuze } \\
& \text { Subject to } e_{s}=\sum_{i=1}^{m} u_{i} y_{i s}-\sum_{j=1}^{m} v_{j} x_{i r} \quad \leq 0, r=1, \ldots N ; \\
& e_{S}=\sum_{j=1}^{m} v_{j} x_{i s}=1 \text { and } \mathrm{u}_{\mathrm{i}} \text { and } \mathrm{v}_{\mathrm{j}} \geq 0
\end{aligned}
$$

In the same way can be converted into a dual linear programming problem:

Minimize $\varepsilon_{\mathrm{s}}$

Subject to $\sum_{r=1}^{n} \varphi_{r} y_{i r}=1, \ldots . ., \mathrm{m} ;$

$$
\varepsilon_{\mathrm{s}} \mathrm{x}_{\mathrm{is}}-\sum_{r=1}^{n} \varphi_{r} x_{i r} \geq 0, \mathrm{j}=\mathrm{I}, \ldots \mathrm{n} ; \varphi_{r} \geq 0 \text {, dan } 0 \leq \varepsilon_{\mathrm{s}} \leq \mathrm{I} \text {. }
$$

While $\varepsilon_{\mathrm{s}}$ is the total value (score) bank-s technical efficiency, the value I signifies the limit point. The equation (3) and (4) assume constant returns to scale (CRS). The limit efficiency line can be seen as commensurate OC. Therefore, banks are in the boundary (line) that is based on efficiency definition from Farrel (1957). Bank-s all located on the right side the limit or inefficient bank described as a point S. Overall, the technical efficiency $\left(\varepsilon_{s}\right)$ is calculated by the ratio of AQ/AS. Thus, the bank-s is to be reduced $\left(I-\varepsilon_{\mathrm{s}}\right)$ of input to achieve efficiency at the point $Q$. 


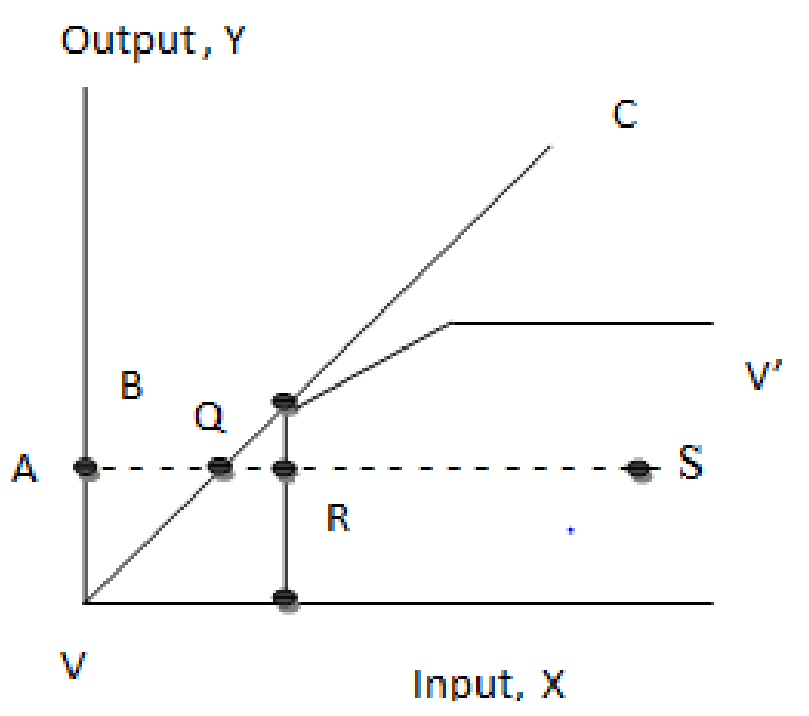

\section{Figure I. Efficiency Measurement Using I Input and I Output}

Scale efficiency is equal to $I$ if and only if technology refers CRS or point $B$. However, scale efficiency can occur due to an increase (IRS) or decrease (DRS) return to scale. To get both of results, the settlement of linear programming equation (3) and (4) should be limited to the $\operatorname{sum} \varphi_{r}$ from I to $N$ is less than or equal to I $(\leq I)$ or OBV. In the approach, it will be assessed thelevelof technical efficiency constant returns to scale (CRS) and the technical efficiency of variable returns to scale (VRS). CRS technical efficiency gives the assumption that if the numbers of inputs risein the amount of $x$, then the output also risesby $X$. In other words, the increase in output is proportional to the increase in input. While the VRS technical efficiency gives the assumption that an increase in output is not proportional with the increase of input, may be larger or smaller than the increase in inputs. In DEA, efficiency states that ratio between the total input andtotal output weighted. Where each unit of economic activity is assumed to freely determine the weight of each variable input and output variables that exist, as long as it is able to meet the two conditions required i.e. Silkman (1986); Nugroho (1995); Wibowo (2004); Lendro Kurniawa (2005); Firdaus (20I3). 
Islamic Banking Efficiency: Comparative Studies

Ika Yulita, Sofyan Rizal

\section{DISCUSSION}

On this discussion, it would be explained the processed result data of Islamic bank (full-fledged Islamic banks) in Malaysia and Indonesia during the first quarter of 2011- the fourth quarter of 2014 by using Data Envelopment Analysis (DEA) intermediation approach, Return to Scale (VRS) variable, and output oriented with input variables Third Party Funds (DPK), Fixed Assets, and Operational Cost and output variables (Total Financing and Total Operating Income).

From the results table on the data with WDEA above, it appears that in 20II, the efficient Islamic bank in Indonesia were Bank of BRI Sharia (BRIS), Bank of BNI Sharia (BNIS), Bank of BCA Sharia (BCAS), Bank of Sharia Mandiri (BSM), Bank of Jabar Banten Sharia (BJBS), and Bank of Mega Sharia (BMS). While banks that experiencing inefficiency are Bank of Muamalat Indonesia (BMI) of 99.91\%, Bank of Sharia Bukopin (BSB) $90.52 \%$, Bank of Panin Sharia (BPS), Maybank Shariah Indonesia (MSI). In 2012, there were only three efficient Islamic banks are BCA Syariah (BCAS), Bank of Sharia Mandiri (BSM), and Bank of Jabar Banten Sharia (BJBS) and the rest are inefficiency.

\section{Level of Islamic Bank Efficiency in Indonesia}

In 2013 was not much different than in 2012 when only three banks were efficient such as: Bank Syariah Mandiri (BSM), Bank Jabar Banten Syariah (BJBS) and the rest were inefficient. The global crisis that occurred in 2012 and 2013 had a significant impact on the performance of Islamic banking in Indonesia. In 20I4, the efficiency performance of Islamic Banks began to improve, there were efficient four banks i.e. BNI Syariah (BNIS), Bank Jabar Banten Syariah (BJBS), Bank Syariah Bukopin (BSB), and Bank Panin Syariah. Only Bank Jabar Banten Syariah (BJBS) was able to achieve efficiencies from 20II to 2014. The Islamic Bank Mandiri (BSM) also achieved perfect efficiency in 20II-2013, just in 2014 alone experienced inefficiency. 
Table 2.Islamic Bank Efficiency in Indonesia from 20 I I to 20 I 4

\begin{tabular}{|c|c|c|c|c|c|c|c|}
\hline \multirow{2}{*}{ No } & \multirow{2}{*}{ Banks } & \multicolumn{4}{|c|}{ Year } & \multirow{2}{*}{ Total } & \multirow{2}{*}{ Mean } \\
\hline & & 2011 & 2012 & 2013 & 2014 & & \\
\hline I & BMI & 99.91 & 88.34 & 91.01 & 83.37 & 362,63 & 90,67 \\
\hline 2 & BRIS & 100 & 99.48 & 95.71 & 99.78 & 394,97 & 98,74 \\
\hline 3 & BNIS & 100 & 93.43 & 95.48 & 100 & 388,91 & 97,23 \\
\hline 4 & BCAS & 100 & 100 & 97.58 & 98.57 & 396,15 & 99,04 \\
\hline 5 & BSM & 100 & 100 & 100 & 95,11 & 395, I I & 98,78 \\
\hline 6 & BJBS & 100 & 100 & 100 & 100 & 400 & 100 \\
\hline 7 & BMS & 100 & 99.27 & 100 & 96.34 & $395,6 \mathrm{I}$ & 98,90 \\
\hline 8 & BSB & 90.52 & 89.43 & 96.23 & 100 & 376,18 & 94,04 \\
\hline 9 & BPS & 96.02 & 98.30 & 96.37 & 100 & 390,69 & 97,67 \\
\hline 10 & $\mathrm{MSI}$ & 95.87 & 96.86 & 98.76 & 99.01 & 390,50 & 97,62 \\
\hline \multirow{2}{*}{\multicolumn{2}{|c|}{ Total Mean }} & 982.32 & 965. I I & 971.14 & 972.18 & & \\
\hline & & 98.23 & $96.5 \mathrm{I}$ & 97.14 & 97.21 & & \\
\hline
\end{tabular}

Source: Data processed using WDEA (VRS assumption)

Based on the processed data in figure 2, the overall growth rate of the Islamic banks efficiency in Indonesia has fluctuated due to the trend of individual efficiency levels also fluctuate. During the study period, the score achieved that the highest Islamic bank efficiency was by Bank of Jabar Banten Sharia (100\%) and the lowest efficiency was achieved by Bank of Muamalat Indonesia amounted to $90.67 \%$. Based on the results of the efficiency measures that the Islamic banks, which achieved a score of $100 \%$ can be interpreted that the bank has been able to optimize all its resources and were efficient categorized bank. 
Islamic Banking Efficiency: Comparative Studies

Ika Yulita, Sofyan Rizal

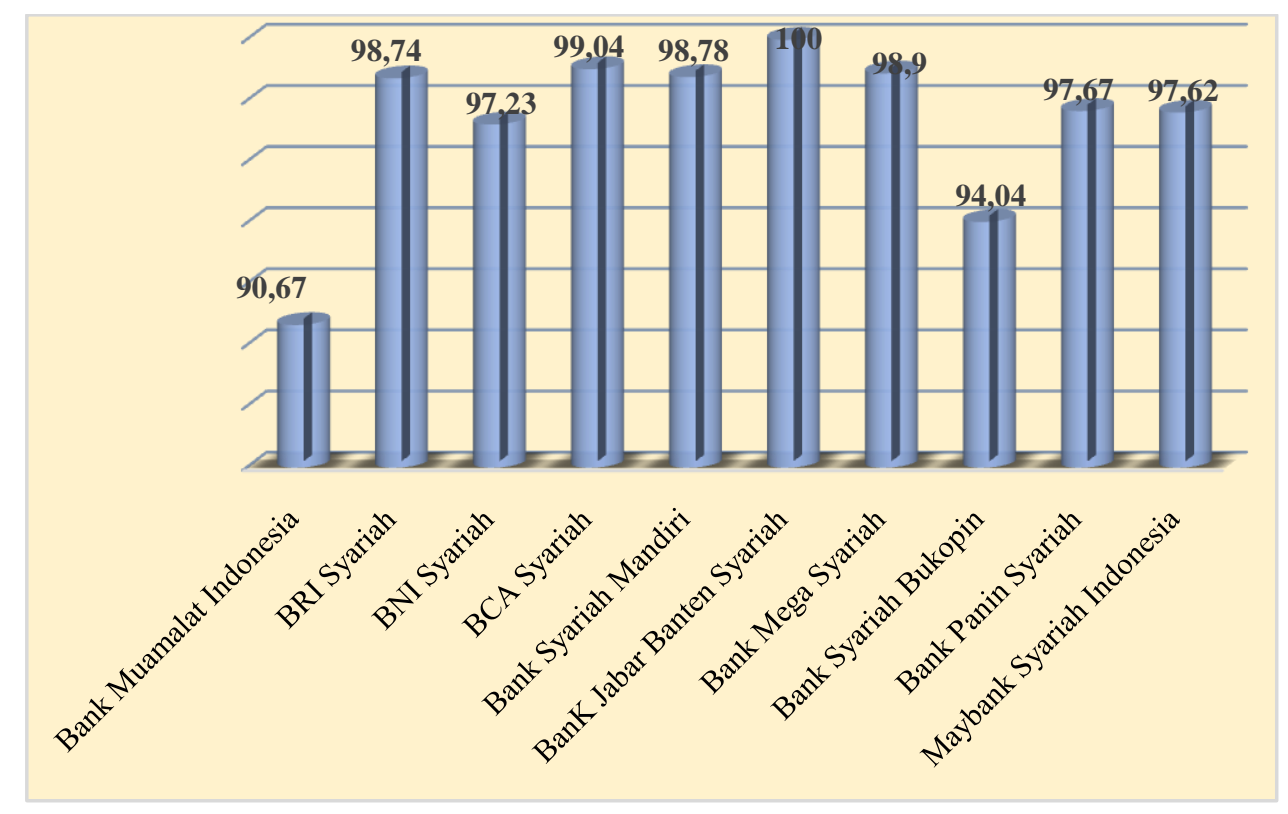

Figure 2. Efficiency of 10 Islamic Bank in Indonesia on Average

first quarter of $20 \mathrm{II}$ - the fourth quarter of $20 \mathrm{I} 4$

Source: Data processed using WDEA (VRS assumption)

\section{Level of Islamic Bank Efficiency in Malaysia}

Based on the data processing WDEA results, Islamic banks in Malaysia was still not possible to say efficiently, because of its efficiency scores only reached between $84 \%$ and $99 \%$. In 20II, Islamic banks in Malaysia areefficient only three banks i.e. Bank Islam Malaysia Berhad (BIM), Amlslamic Bank Berhad (AMIB), and OCBC Al-Amin Malaysia Berhad (OAM), and experiencing inefficiency were Affin Islamic Bank Berhad (AFIB), Alliance Islamic Bank Berhad (ALIB), Asian Finance Bank (AFB), Bank Muamalat Malaysia Berhad (BMM), Hong Leong Islamic Bank Berhad (HLIB), and Al-Rajhi Banking and Investment Corporation (Malaysia) Berhad. In 2012, all Islamic banks in Malaysia were experiencing inefficient. In 2013, the performanceof Islamic banking in Malaysia was still not efficient. There was only one bank that was efficient, i. e. Hong Leong Islamic Bank Berhad (HLIB). This indicated that the global economic turmoil that occurred between 2012 and 2013 had a severe impact that to Islamic banking in Malaysia. Finally in 2014, the efficiency performance of Islamic banking in Malaysia began to improve. There were six banks that were able to achieve perfect efficiency i.e. Alliance Islamic Bank Berhad (ALIB), Bank Islam Malaysia Berhad (BIM), 
Asian Finance Bank Berhad (AFB), Bank Muamalat Malaysia Berhad (BMM), Hong Leong Islamic Bank Berhad (HLIB), and Al-Rajhi Banking and Investment Corporation (Malaysia) Berhad. Only three banks were experiencing inefficiencies i.e. Affin Islamic Bank Berhad (AFIB) 98.73\%, Am Islamic Bank Berhad (AMIB) 99.73\%, and OCBC Al-Amin Malaysia Berhad (OAM) 99.61\%, and the rest suffered perfect efficiency.

Table 3.Islamic Bank Efficiency in Indonesia from $20 \mathrm{II}$ to $20 \mathrm{I} 4$

\begin{tabular}{|c|c|c|c|c|c|c|c|}
\hline \multirow{2}{*}{ No } & \multirow{2}{*}{ Banks } & \multicolumn{4}{|c|}{ Year } & \multirow{2}{*}{ Total } & \multirow{2}{*}{ Mean } \\
\hline & & 2011 & 2012 & 2013 & 2014 & & \\
\hline I & AFIB & 97.74 & 84.87 & 96.73 & 98.73 & 378,07 & 94,52 \\
\hline 2 & ALIB & 99.57 & 99.14 & 99.69 & 100 & 398,4 & 99,60 \\
\hline 3 & BIM & 100 & 99.69 & 97.66 & 100 & 397,35 & 99,33 \\
\hline 4 & AMIB & 100 & 96.93 & 98.51 & 99,73 & 395,17 & 98,79 \\
\hline 5 & AFB & 93.11 & 73.37 & 71.75 & 100 & 338,23 & 84,56 \\
\hline 6 & BMM & 93.51 & 91.85 & 98.42 & 100 & 383,78 & 95,94 \\
\hline 7 & OAM & 100 & 98.92 & 99.09 & 99.61 & 397,62 & 99,40 \\
\hline 8 & HLIB & 96.97 & 98.10 & 100 & 100 & 395,07 & 98,77 \\
\hline 9 & ARB & 99.26 & 94.96 & 97.02 & 100 & 391,24 & 97,8 I \\
\hline \multicolumn{2}{|c|}{ Total } & 982.32 & 880,16 & 837,83 & 858,87 & 898,07 & \\
\hline \multicolumn{2}{|c|}{ Mean } & 98.23 & 97,80 & 93,02 & 95,43 & 99,79 & \\
\hline
\end{tabular}

Source: Data processed using WDEA (VRS assumption) 


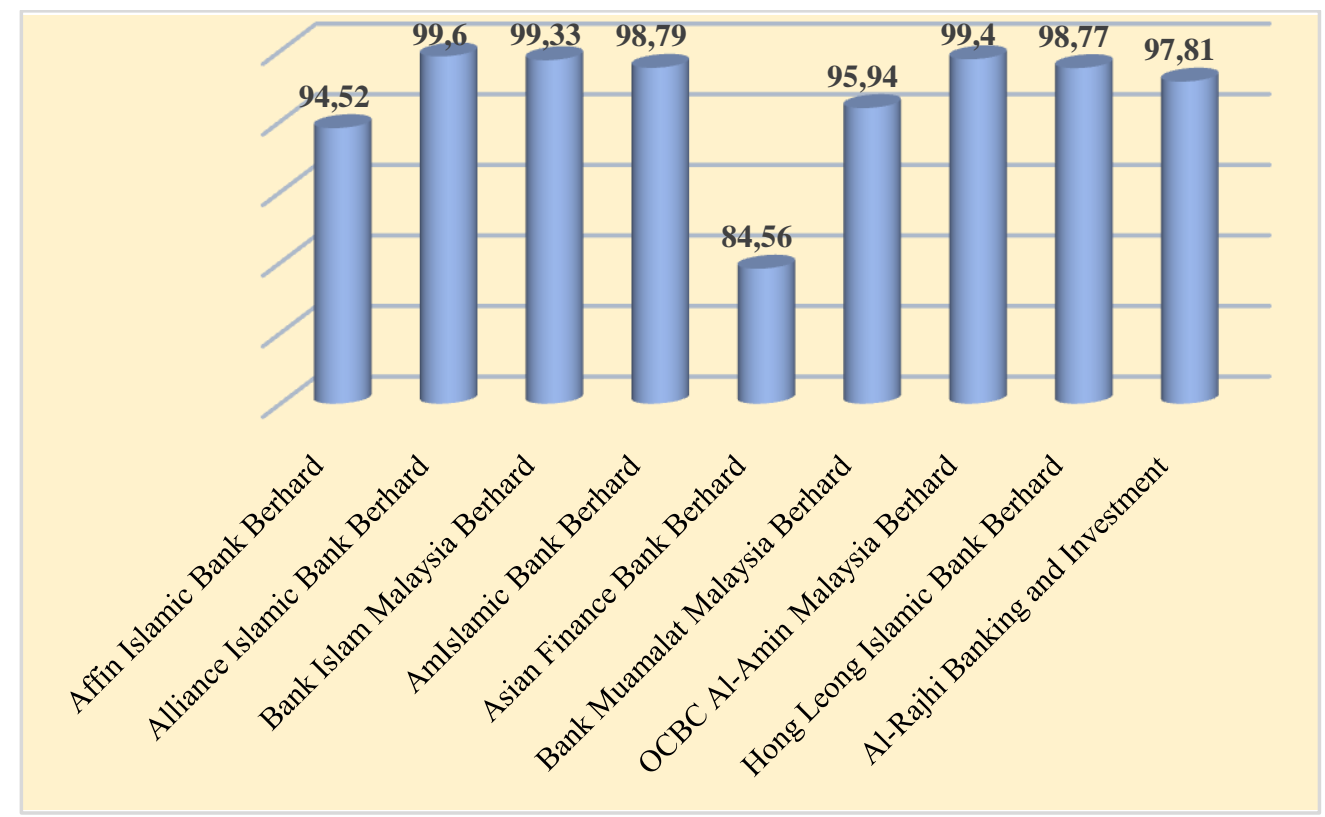

Figure 3. Efficiency of 9 Islamic Bank in Malaysia on Average

first quarter of $20 \mathrm{II}$ - the fourth quarter of 2014

Source: Data processed using WDEA (VRS assumption)

The efficiency performance of Islamic banks in Malaysia fluctuated, because the quarterly data results some banks also experienced fluctuations. Banks who achieved the highest average efficiency score i.e. Alliance Islamic Bank Berhad a mounting to $99.60 \%$, while the Bank which reached the level of the lowest efficiency is Asian Finance Islamic Bank Berhad (AFB). On average Islamic bank in Malaysia has reached the level of efficiency in the range of $80-99 \%$, but cannot achieve perfect efficiency score.

\section{Combining Efficiency Analysis between Indonesia and Malaysia}

From the Figure 4 shows that the average level of Islamic banking efficiency between Indonesia and Malaysia has fluctuated. Blue arrow label leds Indonesia is at the top, it shows that the level of efficiency of Islamic banking in Indonesia was more efficient than the Islamic banks in Malaysia. 


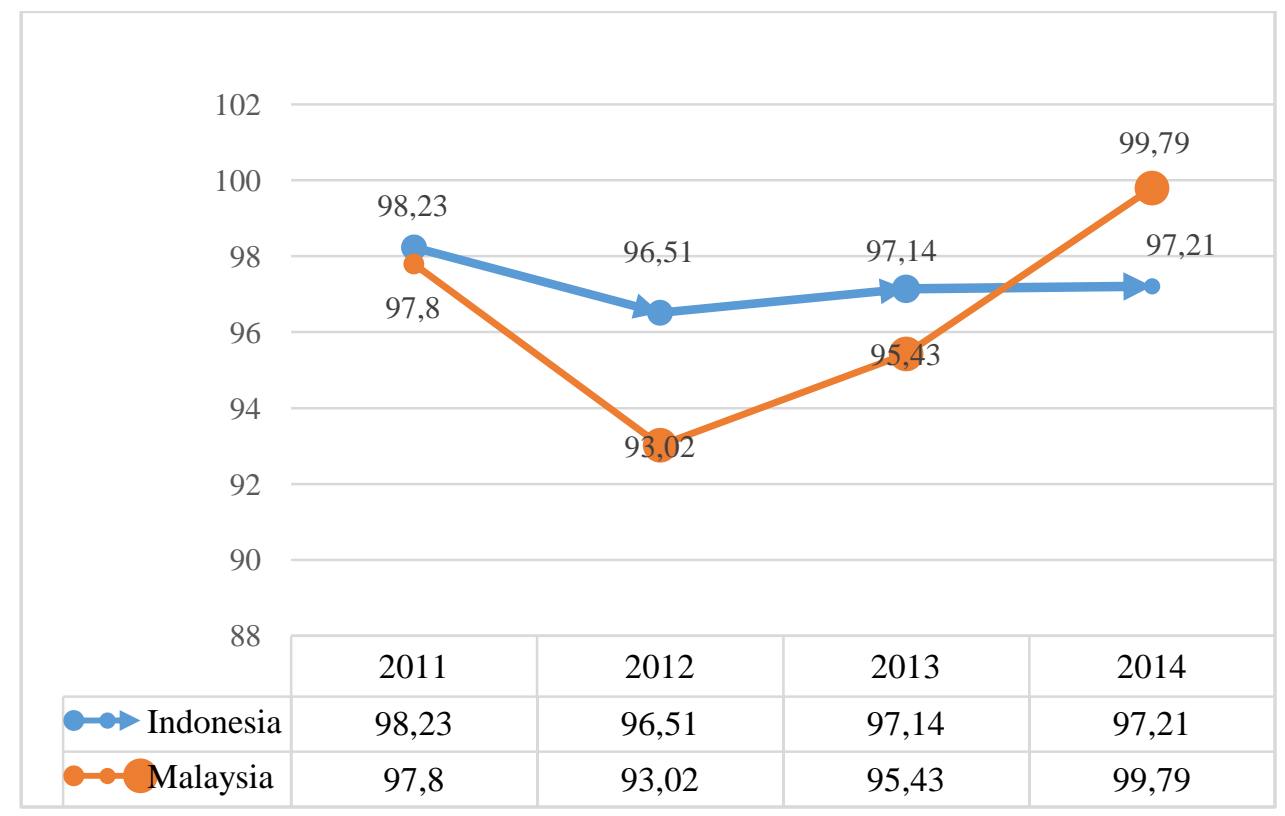

Figure 4. Comparison of Islamic Banking Efficiency between Indonesia and Malaysia

Source: Data processed using WDEA (VRS assumption

Based on these results, while the level of Islamic banking efficiency in Indonesia occurred performance decline trend from 2012 to 20I3, Islamic banks in Malaysia had not been able to achieve good efficiency performance over the period 20II-20I4. The result of this research was in line with previous research by Rossazana Ab-Rahim, Norlina Kadri, and Farhana Ismail (2013) which examined the efficiency of Islamic banking in Malaysia. The Islamic bank in Malaysia cannot achieve perfect efficiency in 20II. The Islamic bank in Indonesia in $20 \mathrm{II}$ and 2014 fluctuated and cannot besaid to be efficient because efficiency scores of which was in the range of $90-99 \%$, the same as a previous study by Faza Muhammad Firdaus in 2013 which examined Islamic Banks by DEA method 2005-20 I I period, where in 20 I I the Islamic Bank in Indonesia still cannot achieve perfect efficiency rate at the level of $100 \%$.

\section{Total Potential Improvement of Islamic Bank in Indonesia and Malaysia}

In this study the authors tried to process the data obtained from WDEA to achieve the total potential improvement to be repaired because the inefficiency due to the occurrence of shortage or excess in the variable input (DPK, personnel burden, fixed assets) and output (total financing and operational income). From the figure 6, the 
Islamic Banking Efficiency: Comparative Studies

Ika Yulita, Sofyan Rizal

total improvement (variables that need improvement) contained in the variable input and output. Variable input includes DPK, fixed assets, and personnel burden. Then a variable output that needs to be addressed is the total financing and operational income. Total financing of the largest contributors that cause inefficiency in Islamic banking in Indonesia at $41 \%$, Islamic banks contributor to the total financing of the greatest inefficiencies are Bank Panin Syariah amounted to $269.0 \%$ and May bank Syariah Indonesia amounted to $153.8 \%$ while an efficient variable is operational income with a score of $7 \%$. Later in Malaysia, the biggest contributor of fixed assets caused of inefficiency of $38 \%$ and an efficient variable includes the total financing and operational income with the score the same at $6 \%$.
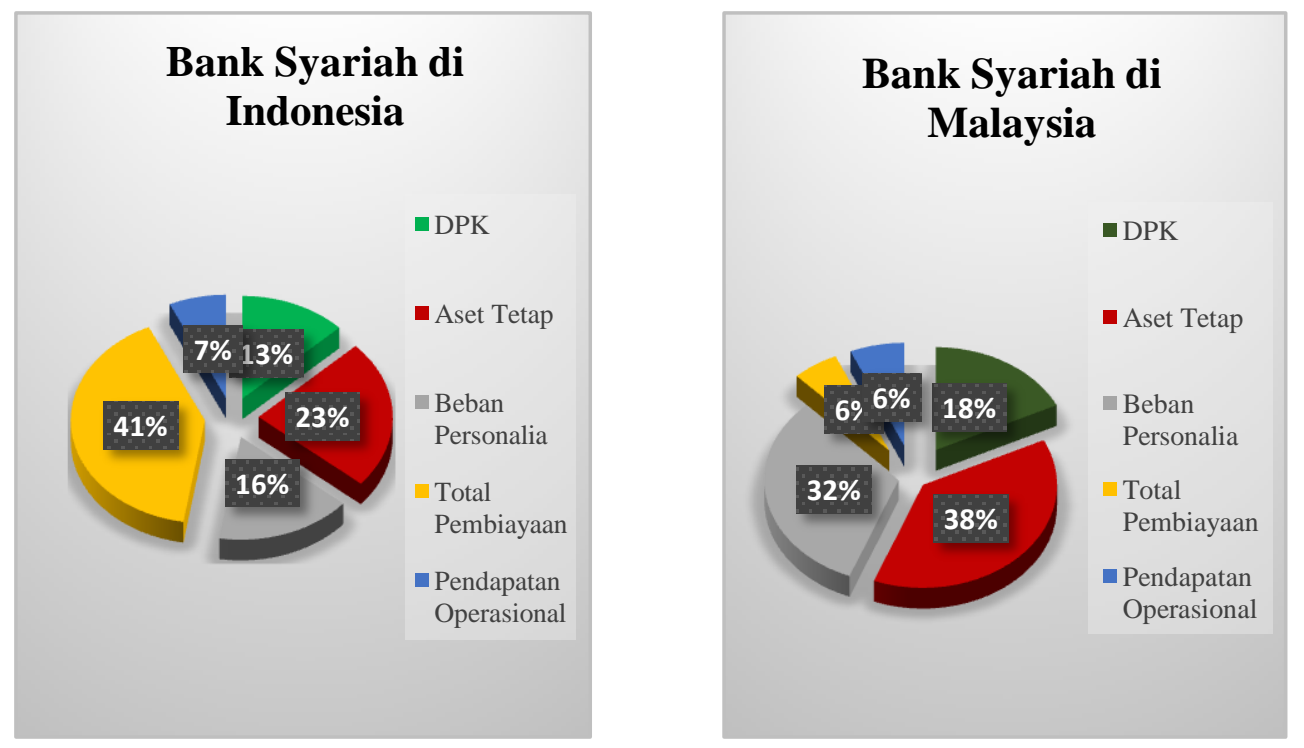

Figure 5. Total Potential Improvement of Islamic Bank in Indonesia and Malaysia

Source: Data processed using WDEA (VRS assumption

Islamic banking in Indonesia experienced inefficiencies in third party funds (DPK) while the total financing distribution was minus. The results of this study in lined with the research that has been done by Faza Paradise (2012) where the main cause of inefficiency in the measurement of efficiency was total financing variable while the research has been done by Asep Saefullah (20/3) stated that personnel burden variable was inefficient. Differences in these results may be affected by a number of samples and the time period used in this study. 
Fixed assets are tangible assets include buildings, office equipment, vehicles, land, ATM machines, etc. Actually, this can be minimized with the cooperation between Islamic banks with the parent bank to reduce the cost of fixed asset, for example with a strategy ATM joint, mutual insurance, optimization of office channelling, Optimization in providing joint ATM was necessary so that customers who are in disadvantaged areas can access Islamic banking facilities without having to incur huge costs, as well as management of Islamic banking should be to educate employees on asset management in order to achieve efficient use of existing fixed assets.

Expenses for personnel burden conducted due to Islamic banking expansion. When the number of employees increased, the cost of personnel increased. Recruiting Sharia human resources can minimize Islamic banking fees in the cost of training and education of human resources. Human resource comes from graduates who are in the whole college that opened banking and Islamic economic program in order to save human resources education funding. With the number of human resources understanding Islamic banking can improve the performance of banking with innovative products and providing excellent services in developing Islamic financial institutions in high competitiveness. From the side of the regulator (OJK and $\mathrm{BNM})$ can contribute in making policies on human resource rules more comprehensible by determining the minimum limit of personnel burden that must be issued.

\section{Kolmogorov-Smirnov Test}

To determine whether there is a significance difference in the level of efficiency of Islamic banking in Indonesia and Malaysia, the testing of nonparametric statistics using the software SPSS 20 is needed, where the first thing to do with examining the data on the DEA analysis normality test Kolmogorov-Smirnov to be known normally distributed data or not, when normal use independent test t-test to determine differences in efficiency results but if not normally distributed, then tested the MannWhitney U-test. From the results of data normality test with KolmogorovSmirnov, the test resulted produce value Asymp. Sig. (2-tailed) for .000 whichis less than 0.05 which means that the data were not normally distributed. Therefore, 
Islamic Banking Efficiency: Comparative Studies

Ika Yulita, Sofyan Rizal

testing the significance of differences is done by using the Mann Whitney UTest.

Table 4. One Sample Kolmogorov-Smirnov Test

\begin{tabular}{llr}
\hline & & Islamic Bank Efficiency \\
\hline N & & 304 \\
Normal Parameters ${ }^{\mathrm{a}, \mathrm{b}}$ & Mean & 9690,43 \\
& Std. Deviation & 661,439 \\
Most Extreme & Absolute &, 348 \\
Differences & Positive &, 320 \\
& Negative &,- 348 \\
Kolmogorov-Smirnov Z & & 6,065 \\
Asymp. Sig. (2-tailed) & &, 000 \\
\hline a. Test distribution is Normal. & \\
b. Calculated from data. &
\end{tabular}

Table 5. Mann-Whitney U-Test

Ranks

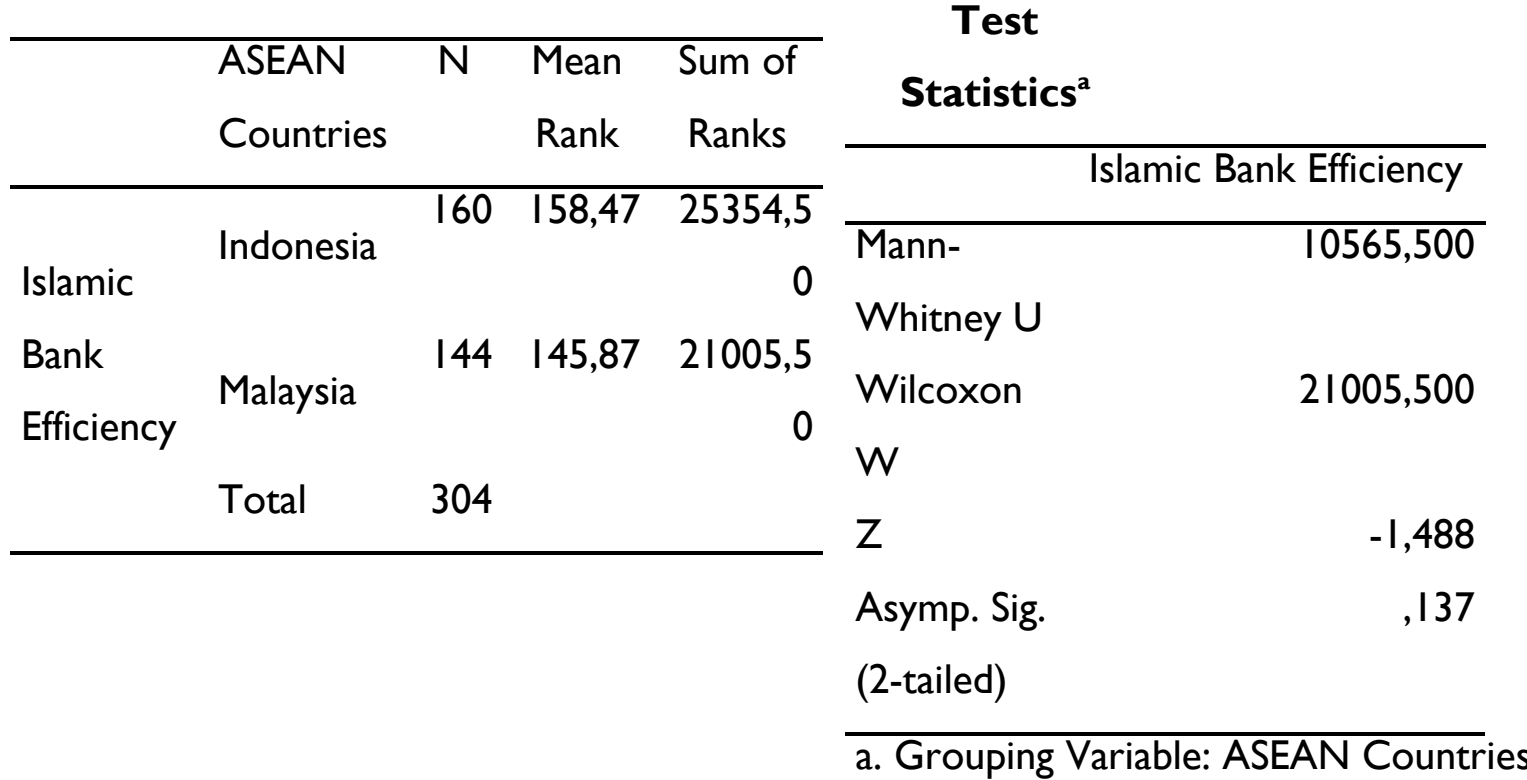

According to the Table 4 and Table 5, it can be seen on test Statistics related to tests of significance level of efficiency Islamic bank in Indonesia and Islamic banks in Malaysia (Sig 0.137> 0.05) and table values mean Indonesia rank larger than Malaysia 
thus proving that the level of efficiency of Islamic banks in Indonesia is different from the Islamic banks in Malaysia.

Table 6. Dummy Variable Regression Test

Model Summary

\begin{tabular}{llccc}
\hline Model & R & R Square & $\begin{array}{c}\text { Adjusted R } \\
\text { Square }\end{array}$ & $\begin{array}{c}\text { Std. Error of } \\
\text { the Estimate }\end{array}$
\end{tabular}

\begin{tabular}{lllll}
\hline $\mathrm{l}$ &, $054^{\mathrm{a}}$ &, 003 & 000 & $6,617 \mathrm{II}$
\end{tabular}

a. Predictors: (Constant), Dummy (Malaysia= I, dan Indonesia=0)

b. Dependent Variable: DEA

ANOVA $^{\mathrm{a}}$

\begin{tabular}{|c|c|c|c|c|c|c|}
\hline \multirow[t]{2}{*}{ Model } & & $\begin{array}{l}\text { Sum of } \\
\text { Squares }\end{array}$ & Df & Mean Square & $F$ & Sig. \\
\hline & Regression & 38,308 & $\mathrm{I}$ & 38,308 & ,875 & $350^{b}$ \\
\hline \multirow[t]{2}{*}{ I } & Residual & I 3223,428 & 302 & 43,786 & & \\
\hline & Total & $|326|, 736$ & 303 & & & \\
\hline
\end{tabular}

a. Dependent Variable: DEA

b. Predictors: (Constant), Dummy

Coefficients $^{a}$

\begin{tabular}{|c|c|c|c|c|c|c|}
\hline \multirow{2}{*}{\multicolumn{2}{|c|}{ Model }} & \multicolumn{2}{|c|}{$\begin{array}{c}\text { Unstandardized } \\
\text { Coefficients }\end{array}$} & \multirow{2}{*}{$\begin{array}{l}\text { Standardized } \\
\text { Coefficients } \\
\text { Beta }\end{array}$} & \multirow[t]{2}{*}{$\mathrm{T}$} & \multirow[t]{2}{*}{ Sig. } \\
\hline & & $B$ & Std. Error & & & \\
\hline \multirow{2}{*}{ I } & (Constant) & 97,245 &, 523 & & 185,890 & , 000 \\
\hline & Dummy & | & ,760 &,- 054 &,- 935 & 350 \\
\hline
\end{tabular}

a. Dependent Variable: DEA

Source: Data processed from SPSS 20

In the table the table 6 , the value of $R$ Square is 0.003 . It means that the role or Dummy variable contribution of country can only explain $0.3 \%$. Significant value of $0.350>0.05$ explains that factors other countries (Malaysia and Indonesia) has no effect on the efficiency of the DEA. It can be concluded that, DEA efficiency Islamic banks in Malaysia and Indonesia is different. 
Islamic Banking Efficiency: Comparative Studies

Ika Yulita, Sofyan Rizal

\section{CONCLUSION}

Overall, Islamic banking efficiency level in Indonesia and Malaysia tend to fluctuate. In Indonesia, the movement of efficiency level of Bank Syariah Mandiri (BSM) and Bank Jabar Banten Syariah (BJBS) tend to be stable. However, the performance efficiency of Bank Jabar Banten Syari

ah (BJBS) is much more efficient than the entire Islamic bank in Indonesia. The most inefficient bank in this study period in was Bank Muamalat Indonesia (BMI) with an average efficiency about only $90.67 \%$. It was smaller than other Islamic banks. Islamic banks in Malaysia, which reached the lowest level of efficiency is the Asian Finance Bank Berhad which reached an average efficiency about $84.56 \%$, lower than the Bank Muamalat Indonesia while Islamic banks in Malaysia that reached the highest level of efficiency was the Alliance Islamic Bank Berhad with an average efficiency of $99.60 \%$.

Operational income variable income was the variable that most small contribution to that inefficiency of Islamic banks causes in Indonesia and Malaysia. While the most contributor variable to the cause inefficiency in Islamic banks in Indonesia was total financing variable and in Malaysia wasfixed assets variable. The banks and regulators must consider financing strategy. Expansive activities that are less controlled also resulted to the personnel burden and over fixed asset target. Therefore, it should be the policy of both the internal bank and regulators in Islamic banking to improve efficiency resulting in acceleration of Islamic banking and in 2015 MEA, Islamic banking can play an active role in the global financial markets.

\section{REFERENCES}

Ab-Rahim, et.al. (20/3). Efficiency performance of Malaysian Islamic bank. Malaysia: Munich Personal RePEc Archive (MPRA).

Adawiyah, W.R. (20I5). The Impact of Financial Liberalization on Islamic Bank's Efficiency in Indonesia. Al-lqtishad: Jurnal Ilmu Ekonomi Syariah (Journal of Islamic Economics), Vol. 7 (2), pp. I4I -I50.

Arifin, Z. (20I4). Perkembangan Bank Islam di Indonesia (The development of Islamic Bank in Indonesia). Bekasi: Gramata Publishing. 
Ascarya \& D. Yumanita. (2008a). Measuring the Competitiveness of Islamic Banking in Indonesian Dual Banking System. Tazkia Islamic Finance and the Business Review, Vol. 3 (2), pp. 72-89

Ascarya \& D. Yumanita. (2008b). Comparing the Efficiency of Islamic Banks in Malaysia and Indonesia. Buletin Ekonomi dan Moneter Indonesia, Vol. I I, (2), PP. 95-II 9.

Efendić, V. (20I0). Efficiency of the Banking Sector of Bosnia-Herzegovina with Special Reference to the Relative Efficiency of the Existing Islamic Bank. Bosnia: 8th International Conference on Islamic Economics and Finance.

Fauzi, A. (20I4.) Bank Pembiayaan Rakyat Syariah (BPRS) Indonesia: Apakah Efisien dalam Profitabilitas Operasional (The Indonesian Islamic Rural Bank: Is Efficient in Operational Profitability?) Bogor: Forum Riset Ekonomi dan Keuangan Syariah.

Firdaus, M.F.\& M.N. Hosen. (2013).Efficiency of Islamic Banks Two Stage Method Using Data Envelopment Analysis. Buletin Ekonomi dan Moneter Indonesia, Vol. 16 (2), PP. $155-176$

Ghani, A B. \& A B. Mumin. (1999). Sistem Keuangan Islam dan Pelaksanaannya di Malaysia (Islamic Financial Systems and Implementation in Malaysia). Kuala Lumpur: Jabatan Kemajuan Islam Malaysia.

Hosen, M.N. \& R. Rahmawati. (2016). Efficiency and Profitability on Indonesian Islamic Banking Industry. Al-lqtishad: Jurnal Ilmu Ekonomi Syariah Uournal of Islamic Economics), Vol. 8 (I), pp. 33-48.

Islamic Financial Services Board. Islamic Finance Service Industry Stability Report 2013. Retrieved on March 30, 2015 from http://www.ifsb.org

John, J.et.al. (20I2). Efficiency in Islamic and conventional banks: Evidence from the Gulf Cooperation Council countries. London: Department of Economics Lancaster University Management School Lancaster University LAI 4YX United Kingdom.

Muhari, S. (20I3). The level of efficiency of SRB in Indonesia: Comparison with DEA and SFA methods Relation to CAMEL. (Unpublished Thesis). Jakarta: UIN Syarif Hidayatullah Jakarta.

Malaysia International Islamic Finance Centre (MIFC). "Sustained Growth In Emerging Asia: Regional Expansion Offers For Islamic Finance" . The report is accessible on December 3, 2014 from http://www.mifc.com. 
Islamic Banking Efficiency: Comparative Studies

Ika Yulita, Sofyan Rizal

Rashedul Hoque, Md \& Md. Israt Rayhan. (2012). Data Envelopment Analysis of Banking Sector In Bangladesh. Bangladesh: Institute of Statistical Research and Training, University of Dhaka.

Saefullah, A.(20I3).Efisiensi Perbankan Indonesia: Komparasi, Evaluasi dan Solusi (Efficiency Banking Indonesia: Comparison, Evaluation, and Solutions).Forum Riset Ekonomi dan Keuangan Syariah.

Tanjung, H.\& A. Devi.(20I3).Metodologi Penelitian Ekonomi Islam (Methodology of Islamic Economics Research). Jakarta: Gramata Publishing.

Wahab, Abdul, Mohammed Nadratuzzaman Hosen \& Syafaat Muhari. 2014. Comparison of technical efficiency Conventional Commercial Bank (BUK) and Islamic Banks (BUS) in Indonesia with the method of Data Envelopment analiysis. Al-lqtishad: Jurnal IImu Ekonomi Syariah (Journal of Islamic Economics), Vol. 6 (2), pp. 179-194.

Warninda, T.D. \& M.N. Hosen. (20I5). Mapping and Correlation Analysis of Efficiency and Profitability: The Case of Islamic Rural Bank in Indonesia. AlIqtishad: Jurnal Ilmu Ekonomi Syariah (Journal of Islamic Economics), Vol. 7 (I), Pp. $1-12$ 